\title{
Ion-specific Limitations of Sodium Chloride and Calcium Chloride on Growth, Nutrient Uptake, and Mycorrhizal Colonization in Northern and Southern Highbush Blueberry
}

\author{
David R. Bryla and Carolyn F. Scagel \\ U.S. Department of Agriculture, Agricultural Research Service, Horticultural Crops Research \\ Unit, 3420 NW Orchard Avenue, Corvallis, OR 97330 \\ Scott B. Lukas \\ Department of Horticulture, Oregon State University, Hermiston Agricultural Research and \\ Extension Center, Hermiston, OR 97838 \\ Dan M. Sullivan \\ Department of Crop and Soil Science, Agricultural and Life Sciences Building 3017, Oregon \\ State University, Corvallis, OR 97331
}

\begin{abstract}
AdDitIONAL INDEX wORDS. electrical conductivity, ericaceous mycorrhizal fungi, salinity, Vaccinium
Abstract. Excess salinity is becoming a prevalent problem for production of highbush blueberry (Vaccinium $\mathbf{L}$. section Cyanococcus Gray), but information on how and when it affects the plants is needed. Two experiments, including one on the northern highbush (Vaccinium corymbosum L.) cultivar, Bluecrop, and another on the southern highbush $(V$. corymbosum interspecific hybrid) cultivar, Springhigh, were conducted to investigate their response to salinity and assess whether any suppression in growth was ion specific or due primarily to osmotic stress. In both cases, the plants were grown in soilless media (calcined clay) and fertigated using a complete nutrient solution containing four levels of salinity [none (control), low $\left(0.7-1.3 \mathrm{mmol} \cdot \mathrm{d}^{-1}\right)$, medium $\left(1.4-3.4 \mathrm{mmol} \cdot \mathrm{d}^{-1}\right)$, and high $\left(2.8-6.7 \mathrm{mmol}^{-1}\right)$ ] from either $\mathrm{NaCl}$ or $\mathrm{CaCl}_{2}$. Drainage was minimized in each treatment except for periodic determination of electrical conductivity (EC) using the pour-through method, which, depending on the experiment, reached levels as high as 3.2 to $6.3 \mathrm{dS} \cdot \mathrm{m}^{-1}$ with $\mathrm{NaCl}$ and 7.8 to $9.5 \mathrm{dS} \cdot \mathrm{m}^{-1}$ with $\mathrm{CaCl}_{2}$. Total dry weight of the plants was negatively correlated to EC and, depending on source and duration of the salinity treatment, decreased linearly at a rate of 1.6 to 7.4 $\mathrm{g} \cdot \mathrm{dS}^{-1} \cdot \mathrm{m}^{-1}$ in 'Bluecrop' and 0.4 to $12.5 \mathrm{~g} \cdot \mathrm{dS}^{-1} \cdot \mathrm{m}^{-1}$ in 'Springhigh'. Reductions in total dry weight were initially similar between the two salinity sources; however, by the end of the study, which occurred at 125 days in 'Bluecrop' and at 111 days in 'Springhigh', dry weight declined more so with $\mathrm{NaCl}$ than with $\mathrm{CaCl}_{2}$ in each part of the plant, including in the leaves, stems, and roots. The percentage of root length colonized by mycorrhizal fungi also declined with increasing levels of salinity in Bluecrop and was lower in both cultivars when the plants were treated with $\mathrm{NaCl}$ than with $\mathrm{CaCl}_{2}$. However, leaf damage, which included tip burn and marginal necrosis, was greater with $\mathrm{CaCl}_{2}$ than with $\mathrm{NaCl}$. In general, $\mathrm{CaCl}_{2}$ had no effect on uptake or concentration of $\mathrm{Na}$ in the plant tissues, whereas $\mathrm{NaCl}$ reduced $\mathrm{Ca}$ uptake in both cultivars and reduced the concentration of $\mathrm{Ca}$ in the leaves and stems of Bluecrop and in each part of the plant in Springhigh. Salinity from $\mathrm{NaCl}$ also resulted in higher concentrations of $\mathrm{Cl}$ and lower concentrations of $\mathrm{K}$ in the plant tissues than $\mathrm{CaCl}_{2}$ in both cultivars. The concentration of other nutrients in the plants, including $\mathrm{N}, \mathrm{P}, \mathrm{Mg}, \mathrm{S}, \mathrm{B}, \mathrm{Cu}, \mathrm{Fe}, \mathrm{Mn}$, and $\mathrm{Zn}$, was also affected by salinity, but in most cases, the response was similar between the two salts. These results point to ion-specific effects of different salts on the plants and indicate that source is an important consideration when managing salinity in highbush blueberry.
\end{abstract}

Soil salinity is becoming an increasing problem for production of blueberry (Vaccinium section Cyanococcus), particularly in arid and semiarid regions. Under such conditions, salts, which

Received for publication 10 May 2021. Accepted for publication 3 Aug. 2021. Published online 17 September 2021.

Funds for this research were provided by the Northwest Center for Small Fruits Research and the U.S. Department of Agriculture (CRIS number 2072-21000-048-00D). We thank Jesse Mitchell, Suean Ott, and Brett Gholson for technical assistance and Fall Creek Farm \& Nursery for providing plants. Mention of trade names or commercial products in this publication is solely for the purpose of providing specific information and does not imply recommendation or endorsement by the U.S. Department of Agriculture.

D.R.B. is the corresponding author. E-mail: david.bryla@usda.gov.

This is an open access article distributed under the CC BY-NC-ND license (https://creativecommons.org/licenses/by-nc-nd/4.0/). can originate from soil parent material (weathered rocks and minerals) or the soilless media in which the plants are grown, irrigation water, fertilizers, and amendments such as elemental sulfur (often used to reduce soil $\mathrm{pH}$ ), manures, and composts, are not readily leached (Richards, 1954). As a result, salts accumulate in the soil or growing media and affect many processes, including vegetative and reproductive growth, soil physical properties, and sufficiency and toxicity of nutrients (Munns, 1993). Although options to reduce salinity are available, knowing exactly at what level salts will limit growth and production of a crop is critical for developing cost-effective salt management programs (Horneck et al., 2007).

Like most perennial fruit crops, blueberry has a low salt tolerance (Bernstein, 1964) and tends to be most susceptible to 
salinity during establishment (Bryla and Machado, 2011; Vargas and Bryla, 2015). Patten et al. (1989) suggested maintaining the $\mathrm{EC}$ (or amount of salts) in the saturation extract $\left(\mathrm{EC}_{\mathrm{e}}\right)$ at $<1.5$ $\mathrm{dS} \cdot \mathrm{m}^{-1}$ to produce optimum growth in rabbiteye blueberry ( $\mathrm{Vac}$ cinium virgatum Aiton). Machado et al. (2014) recommended a similar threshold for northern highbush blueberry $(V$. corymbosum), after they examined the effects of salinity induced by application of ammonium sulfate fertilizer under controlled conditions in a greenhouse. However, Messiga et al. (2018) found that yield declined at $\mathrm{EC}_{\mathrm{e}}$ levels as low as $0.8 \mathrm{dS} \cdot \mathrm{m}^{-1}$ as a result of fertilizing with $\mathrm{K}_{2} \mathrm{SO}_{4}$ under field conditions in northern highbush blueberry. Salinity also reduced photosynthesis when $\mathrm{EC}_{\mathrm{e}}$ was at $0.7 \mathrm{dS} \cdot \mathrm{m}^{-1}$ when $\mathrm{K}_{2} \mathrm{SO}_{4}$ was used in cranberry [Vaccinium macrocarpon Aiton (Samson et al., 2017)]. The preceding discrepancies may originate from differences among the plant species, the texture and water capacity of the soil, and the composition of the salts.

Plant response to salinity appears to occur in two distinct phases, including an osmotic phase that over time is followed by an ion-specific phase (Munns and Tester, 2008). During the osmotic phase, salt concentrations surrounding the roots reach a threshold level that negatively impacts plant water relations and reduces leaf expansion and new shoot growth. Curiously, shoot growth is more sensitive than root growth to salinity, a phenomenon that also occurs when plants are exposed to drying soils and for which there is no mechanistic explanation yet. The ion-specific phase is slower to develop and begins when salts accumulate to toxic levels in leaves, which eventually become necrotic and die. When leaf necrosis exceeds new leaf production, the photosynthetic capacity of the plant decreases and its growth is reduced even further. Ionic stress usually impacts plant growth much later than osmotic stress, especially at low to moderate salinity levels. In many crops, salinity tolerance during the ionic phase depends on the ability of the root system to exclude and limit translocation of toxic ions such as $\mathrm{Na}^{+}$and $\mathrm{Cl}^{-}$to aboveground parts of the plant (Munns, 2002). However, blueberry plants appear to be poor excluders of $\mathrm{Na}^{+}$and $\mathrm{Cl}^{-}$and rapidly accumulate toxic levels of these ions in the leaves (Ballinger, 1962; Muralitharan et al., 1992; Wright et al., 1993, 1995).

Depending on the composition of the solution in the root environment, ion toxicities or nutritional deficiencies may arise in plants because of predominance of specific ions or competition among these ions (Shannon et al., 1994). Most research on salinity effects on horticultural crops has focused on $\mathrm{NaCl}$. However, $\mathrm{CaCl}_{2}$ and its ionic form also can be prevalent in soils and irrigation water, as well as in road runoff from deicers, soilless substrates, and fertilizers and pesticides (Grattan and Grieve, 1999). Although both $\mathrm{NaCl}$ and $\mathrm{CaCl}_{2}$ can cause salinity issues, supplementing plants with $\mathrm{CaCl}_{2}$ can reduce damage from $\mathrm{NaCl}$ under certain circumstances (Cramer et al., 1986). This happens because $\mathrm{Ca}$ uptake is inhibited by high concentrations of $\mathrm{Na}$ in the soil, and adding more $\mathrm{Ca}$ can mitigate this issue. However, application of $\mathrm{CaCl}_{2}$ and $\mathrm{CaSO}_{4}$ did not ameliorate the negative effects of $\mathrm{NaCl}$ in rabbiteye blueberry or southern highbush blueberry (V. corymbosum interspecific hybrid) (Wright et al., 1993). In fact, the $\mathrm{Ca}$ salts in this case reduced photosynthesis more than $\mathrm{NaCl}$ alone, suggesting that different types of salt may alter the manner in which blueberry plants respond to salinity.

The objective of the present study was to investigate the response of highbush blueberry to salinity and assess whether growth suppression in the plants was ion specific or primarily due to osmotic stress from the salts. To attain this goal, northern and southern highbush blueberry cultivars were grown in various isosmotic levels of salinity by adding either $\mathrm{CaCl}_{2}$ or $\mathrm{NaCl}$ to a basic nutrient solution. Southern highbush blueberry has much lower chilling requirements (200-300 h) than the northern highbush type $(>800 \mathrm{~h})$ and was developed for production in regions with warmer winters, such as Florida and California (Retamales and Hancock, 2018). Currently, it is unknown whether salinity tolerance differs between them, and we hypothesized that salinity limitations would differ depending on salt type in both types of highbush blueberry. We also examined the percentage of root length colonized by ericoid mycorrhizal fungi in each salinity treatment. These fungi commonly form symbiotic associations with roots of ericaceous plants, including blueberry, and often improve growth by increasing the ability of the plants to acquire immobile soil nutrients such as $\mathrm{NH}_{4}-\mathrm{N}, \mathrm{P}$, and $\mathrm{Zn}$ (Smith and Read, 2008). To our knowledge, there is currently no information on how ericoid mycorrhizal fungi are affected by salinity.

\section{Materials and Methods}

Plant material and growth Conditions. Experiments were conducted in a glasshouse using 'Bluecrop' northern highbush blueberry (Expt. 1) and 'Springhigh' southern highbush blueberry (Expt. 2). The plants in Expt. 1 were obtained from a commercial nursery (Hartmann's Plant Company, Lacota, MI) and transplanted individually into $1.2-\mathrm{L}$ containers [constructed from white polyvinyl chloride $(\mathrm{PVC})$ pipe $(0.5 \mathrm{~m}$ tall $\times 5.5 \mathrm{~cm}$ i.d. $)]$ filled with an inert, calcined, nonswelling illite and silica clay soilless media (Turface; Profile Products, Buffalo Grove, IL). The bottom of each container was covered with fiberglass window screen (secured with a PVC ring cut to fit inside the bottom of the pipe). The plants in Expt. 2 were also obtained from a commercial nursery (Fall Creek Farm \& Nursery, Lowell, OR) but, in this case, were transplanted individually into black, 3.8-L buckets (S-179443BL; Uline, Pleasant Prairie, WI) filled with the calcinated clay media. Three holes $(5.4-\mathrm{cm}$ diameter) were drilled in the bottom of each bucket and covered inside with a circular piece of fiberglass window screen. Each bucket was then nested inside another bucket without holes in a pot-in-pot configuration. A plastic tube (19 mm o.d.) was inserted in the space between the inside and outside buckets to facilitate collection of leachate (see later in this article). Calcinated clay was used in the experiments to reduce confounding soil factors such as changes in availability of soil nutrients at different salinity levels (Grattan and Grieve, 1999) and to facilitate root harvest (roots do not penetrate the particles). Once transplanted, the plants were placed in racks on a greenhouse bench and allowed to become established for $13 \mathrm{~d}$ in Expt. 1 and $65 \mathrm{~d}$ in Expt. 2 before any treatments were applied. Plants were actively growing when they were transplanted in Expt. 1 (July) but not in Expt. 2 (February), and therefore, we waited until new leaves emerged and were fully expanded before initiating the treatments in the second experiment. The plants produced no flowers or fruit during either of the experiments.

Supplemental photosynthetically active radiation $(400-700 \mathrm{~nm})$ was provided from seven $330-\mathrm{W}$ light-emitting diode lamps (ES330; Lumigrow, Novato, CA) over the bench and measured using a quantum light sensor (LI-190SA; LI-COR Biosciences, Lincoln, NE). Air temperature and relative humidity were measured using a shielded temperature/relative humidity sensor 
(1400-104, LI-COR Biosciences). Readings from each sensor were recorded every $15 \mathrm{~min}$ using a data logger (LI-1400; LI-COR Biosciences). In Expt. 1, photosynthetic photon flux density $(P P F D)$ averaged a maximum of $1375 \mu \mathrm{mol} \cdot \mathrm{m}^{-2} \cdot \mathrm{s}^{-1}$ and a total of $20.5 \mathrm{~mol} \cdot \mathrm{m}^{-2} \cdot \mathrm{d}^{-1}$, and temperature and relative humidity averaged $23.9^{\circ} \mathrm{C}$ and $49.9 \%$, respectively. The maximum temperature reached on any given date was $32.7^{\circ} \mathrm{C}$, and the mean minimum temperature was $14.7^{\circ} \mathrm{C}$. Relative humidity ranged from $15.8 \%$ to $72.4 \%$. In Expt. $2, P P F D$ averaged a maximum of $1006 \mu \mathrm{mol} \cdot \mathrm{m}^{-2} \cdot \mathrm{s}^{-1}$ and a total of $24.1 \mathrm{~mol} \cdot \mathrm{m}^{-2}$. $\mathrm{d}^{-1}$. Temperature averaged $26.4^{\circ} \mathrm{C}$ and reached a maximum of $43.7^{\circ} \mathrm{C}$ and a minimum of $19.4^{\circ} \mathrm{C}$. Relative humidity averaged $46.4 \%$ and ranged from $21.9 \%$ to $72.6 \%$.

EXPERIMENTAL DESIGN. The salinity treatments were run for $125 \mathrm{~d}$ in Expt. 1 and $111 \mathrm{~d}$ in Expt. 2. In both cases, the treatments were applied to the plants using a multi drip-line injection system (Aragues et al., 1999), whereby fertilizer solution was added through one drip line and $\mathrm{NaCl}$ and $\mathrm{CaCl}_{2}$ treatments mixed with fertilizer solution were added through two other lines. The system consisted of three water-drive chemical injectors (D14MZ2; Dosatron International, Clearwater, FL). The first injector was used to inject concentrated fertilizer solution into a main line at a 1:50 (v/v) ratio. The solution contained $4.5 \mathrm{~mm}$ $\mathrm{NH}_{4}-\mathrm{N}, 0.8 \mathrm{~mm}$ P, $0.9 \mathrm{~mm} \mathrm{~K}, 0.05 \mathrm{~mm} \mathrm{Ca}, 0.02 \mathrm{~mm} \mathrm{Mg}, 1.9 \mathrm{~mm}$ $\mathrm{S}, 2.8 \mu \mathrm{M} \mathrm{B}, 0.5 \mu \mathrm{M} \mathrm{Cu}, 2.7 \mu \mathrm{M}$ Fe, $0.9 \mu \mathrm{M}$ Mn, $0.1 \mu \mathrm{M}$ Mo, $0.8 \mu \mathrm{M} \mathrm{Zn}$, and $5 \mu \mathrm{M} \mathrm{Cl}$, and, in Expt. 1 only, was adjusted to a $\mathrm{pH}$ of 5.4 using $5 \mathrm{~mm} \mathrm{HCl}$. The main line was then divided into three secondary lines, including one that supplied fertilizer solution to drip emitters in each plant container directly and two others that were used to inject concentrated $\mathrm{NaCl}$ and $\mathrm{CaCl}_{2}$ solutions into tertiary lines with additional drip emitters [see Bryla and Scagel (2014) for details]. Different combination of emitters $\left(2,4\right.$, and $8 \mathrm{~L} \cdot \mathrm{h}^{-1}$; The Toro Co., Bloomington, $\left.\mathrm{MN}\right)$ were selected to provide each salinity treatment with the same volume of fertilizer solution and varying concentrations of $\mathrm{NaCl}$ or $\mathrm{CaCl}_{2}$ in the solution (Table 1). Stock solution molarities, injection ratios, and run times were assessed weekly and altered to address plant growth and changing water needs. The treatments were arranged in a randomized complete block design with six replicates per treatment on each of three destructive harvest dates, for a total of 144 plants $(2$ salt types $\times 4$ salinity levels $\times 3$ harvest dates $\times 6$ replicates) in both experiments. The plants were fertigated daily with minimal amount of drainage, and water content of the media was maintained near container capacity to expose the plants to constant level of $\mathrm{EC}_{\mathrm{e}}$ in each treatment.

Measurements. EC and $\mathrm{pH}$ of the fertigation solutions were measured weekly at $25{ }^{\circ} \mathrm{C}$ using a combination $\mathrm{pH} /$ conductivity meter (SevenGo Pro; Mettler-Toledo, Columbus, OH). Leachate $\mathrm{EC}$ and $\mathrm{pH}$ were also measured weekly, beginning after $8 \mathrm{~d}$ of treatment in Expt. 1 and $5 \mathrm{~d}$ of treatment in Expt. 2. Leachate was collected in both experiments using a pour-through extraction method (Torres et al., 2010). The bottom of each container was fit with a plastic funnel before the pour-through to collect leachate in Expt. 1, and syringes were connected to the tubes installed between the pots to collect leachate in Expt. 2. Distilled water $(125-150 \mathrm{~mL})$ was poured evenly by hand over the surface of each container $30 \mathrm{~min}$ after fertigation, and the extract was allowed to drain for $30 \mathrm{~min}$ into holding vessels. An average of $117 \mathrm{~mL}$ of leachate was collected from eight replicate containers per treatment on each date in Expt. 1, and an average of $110 \mathrm{~mL}$ of leachate was collected from six replicate containers per treatment on each date in Expt. 2. A subsample $(25 \mathrm{~mL})$ of each volume was taken for the $\mathrm{EC}$ and $\mathrm{pH}$ measurements.

Leaves on the plants were evaluated for salt damage beginning at $54 \mathrm{~d}$ of treatment in Expt. 1 and at $1 \mathrm{~d}$ of treatment in Expt. 2. The plants did not show much sign of leaf damage early on in the first experiment, and therefore, evaluations of damage were initiated later in the first than in the second experiment. Symptoms of salt damage included leaf tip burn and marginal necrosis. Leaves showing any signs of these symptoms were considered to have salt damage. The total number of healthy and damaged leaves was counted periodically to calculate the percentage of leaves with salt damage in each treatment.

Plants were harvested destructively after 62, 91, and $125 \mathrm{~d}$ of treatment in Expt. 1 and after 33, 67, and $111 \mathrm{~d}$ of treatment in Expt. 2. On each date, leaves were removed from the stems, and each stem was cut into $\approx 10$-cm-long pieces. The root system was gently removed from the growing substrate, rinsed with water, and cleaned with tweezers to remove any remaining debris. Approximately $1 \mathrm{~g}$ of fresh roots were randomly sampled from each root system and stored in lactoglycerin solution. The leaves, stems, and remaining roots were then oven-dried at $60^{\circ} \mathrm{C}$ for at least $4 \mathrm{~d}$ and weighed. Once weighed, each part was ground to pass through a 40-mesh $(425-\mu \mathrm{m})$ screen and analyzed for $\mathrm{N}$ using a combustion analyzer (TruSpec $\mathrm{CN}$; Leco Corp., St. Joseph, MI); for P, K, Ca, Mg, S, B, Cu, Fe, Mn, Zn, and $\mathrm{Na}$ using inductively coupled plasma optical emission spectrometry (Optima 3000DV; PerkinElmer, Waltham, MA) following microwave digestion in $70 \%(\mathrm{v} / \mathrm{v})$ nitric acid (Gavlak et al., 2005); and for $\mathrm{Cl}$ using an ion-selective electrode (perfectION 51344706, Mettler-Toledo) following extraction in nitric acid (Rieger and Litvin, 1998). Nutrient content was calculated by multiplying the dry weight of each plant part by the concentration of a given nutrient (Chapin and Van Cleve, 1989). Roots stored in lactoglycerin solution were cleared and stained following procedures outlined in Scagel et al. (2005), and examined under a light microscope $(40 \times)$ for the presence of ericoid mycorrhizal fungi. Mycorrhizal colonization was quantified

Table 1. Amount of $\mathrm{NaCl}$ or $\mathrm{CaCl}_{2}$ applied to 'Bluecrop' and 'Springhigh' blueberry plants exposed to four levels of salinity in Expts. 1 and 2 , respectively.

\begin{tabular}{|c|c|c|c|c|c|c|}
\hline \multirow[b]{3}{*}{ Salinity level } & \multicolumn{4}{|c|}{ Expt. 1} & \multicolumn{2}{|c|}{ Expt. 2} \\
\hline & \multicolumn{2}{|c|}{$\mathrm{NaCl}\left(\mathrm{mmol} \cdot \mathrm{d}^{-1}\right)$} & \multicolumn{2}{|c|}{$\mathrm{CaCl}_{2}\left(\mathrm{mmol} \cdot \mathrm{d}^{-1}\right)$} & \multirow{2}{*}{$\frac{\mathrm{NaCl}\left(\mathrm{mmol}^{-1} \mathrm{~d}^{-1}\right)}{\text { Day } 0-111}$} & \multirow{2}{*}{$\frac{\mathrm{CaCl}_{2}\left(\mathrm{mmol} \cdot \mathrm{d}^{-1}\right)}{\text { Day } 0-111}$} \\
\hline & Day 0-91 & Day $92-125$ & Day 0-91 & Day $92-125$ & & \\
\hline Control & 0.0 & 0.0 & 0.0 & 0.0 & 0.0 & 0.0 \\
\hline Low & 0.7 & 1.3 & 1.0 & 1.7 & 0.9 & 0.9 \\
\hline Medium & 1.4 & 2.5 & 1.9 & 3.4 & 1.7 & 1.7 \\
\hline High & 2.8 & 5.0 & 3.8 & 6.7 & 3.4 & 3.4 \\
\hline
\end{tabular}


using a modified grid-line intersect technique and expressed as the percentage of the total root length with internal mycorrhizal structures such as internal hyphae and hyphal coils (Giovannetti and Mosse, 1980).

StatistiCal analyses. All data were analyzed using analytical software (Statistica version 12; StatSoft, Tulsa, OK). The data were checked for normality using the Komogorov-Smirnov test at $P \leq 0.01$, and tested for homogeneity of variance using Levene's test. Biomass allocation and root colonization data were arcsine-transformed before analyses and presented as backtransformed means.

Differences between salt types and among salinity levels were assessed on leaf necrosis using analysis of variance (ANOVA) in a complete factorial design with salt type and salinity level as main effects. Means from ANOVA were separated using Tukey's honestly significant difference test $(P \leq$ $0.05)$. Differences between salt types and among salinity levels were assessed on EC of pour-though leachate using analysis of covariance (ANCOVA) in a complete factorial design with salt type and salinity level as main effects and leachate volume as a covariate. Adjusted means are presented for each salt type and salinity level, and these means were used as a covariate in analyses of plant response variables (described as follows).

Effects of salt type and EC on plant growth, biomass allocation, mycorrhizal colonization, and nutrient uptake and concentration were assessed separately for each harvest date using ANCOVA in a complete factorial design with salt type as a categorical effect and EC as continuous predictor variable. Based on significant ANCOVA results $(P \leq 0.05)$, adjusted means are presented for the two salt types at an EC of $2 \mathrm{dS} \cdot \mathrm{m}^{-1}$, and regression coefficients $(\beta)$ are presented for relationships between EC and the response variables. EC determined by the pour-through method is $\approx 30 \%$ greater than $\mathrm{EC}_{\mathrm{e}}$ (Fisher et al.,
2006) and at $2 \mathrm{dS} \cdot \mathrm{m}^{-1}$ is equivalent to the level of salinity at which plant production is reduced by at least $10 \%$ in salt-sensitive species such as blueberry (Maas and Grattan, 1999). In all regression analyses, the influence of salt type on relationships between EC and response variables was assessed using best subsets regression with the Mallows $C P$ technique as the criterion for choosing the best subset of predictor effects from linear and quadratic models (Mallows, 1973). Differences in $\beta$ between salt types were compared using Z-tests (Paternoster et al., 1998).

\section{Results}

LEaChate EC AND PH. At any given level of salinity, the EC of leachate from the containers and buckets in Expts. 1 and 2, respectively, was greater with $\mathrm{CaCl}_{2}$ than with $\mathrm{NaCl}$ (Fig. 1A and $\mathrm{B}$ ). This difference was expected given that $\mathrm{EC}$ is a measure of milliequivalents of charge per liter, and at each concentration, $\mathrm{CaCl}_{2}$ has twice as many ions as $\mathrm{NaCl}$. Leachate EC also increased over time in Expt. 2, which indicates salt ions accumulated in the lower and wider containers used in the second experiment. By the final harvest, EC was as high as 3.2 and 6.3 $\mathrm{dS} \cdot \mathrm{m}^{-1}$ with $\mathrm{NaCl}$ and $\mathrm{CaCl}_{2}$, respectively, in Expt. 1, and as high as 7.8 and $9.5 \mathrm{dS} \cdot \mathrm{m}^{-1}$ with $\mathrm{NaCl}$ and $\mathrm{CaCl}_{2}$, respectively, in Expt. 2. In contrast, EC of control treatments ranged from 0.4 to $0.7 \mathrm{dS} \cdot \mathrm{m}^{-1}$ on each harvest date in either experiment.

Leachate $\mathrm{pH}$ decreased over time in both experiments but was similar among the salinity treatments (data not shown). In Expt. 1, pH averaged 5.0 at $62 \mathrm{~d}$ of treatment, 4.1 at $91 \mathrm{~d}$, and 3.9 at 125 d. In Expt. 2, pH averaged 5.7 at 33 and $67 \mathrm{~d}$ of treatment and 5.1 at $111 \mathrm{~d}$. As mentioned, the fertilizer solution was acidified with $\mathrm{HCl}$ in the first experiment, which explains why pH was lower in Expt. 1 than in Expt. 2.
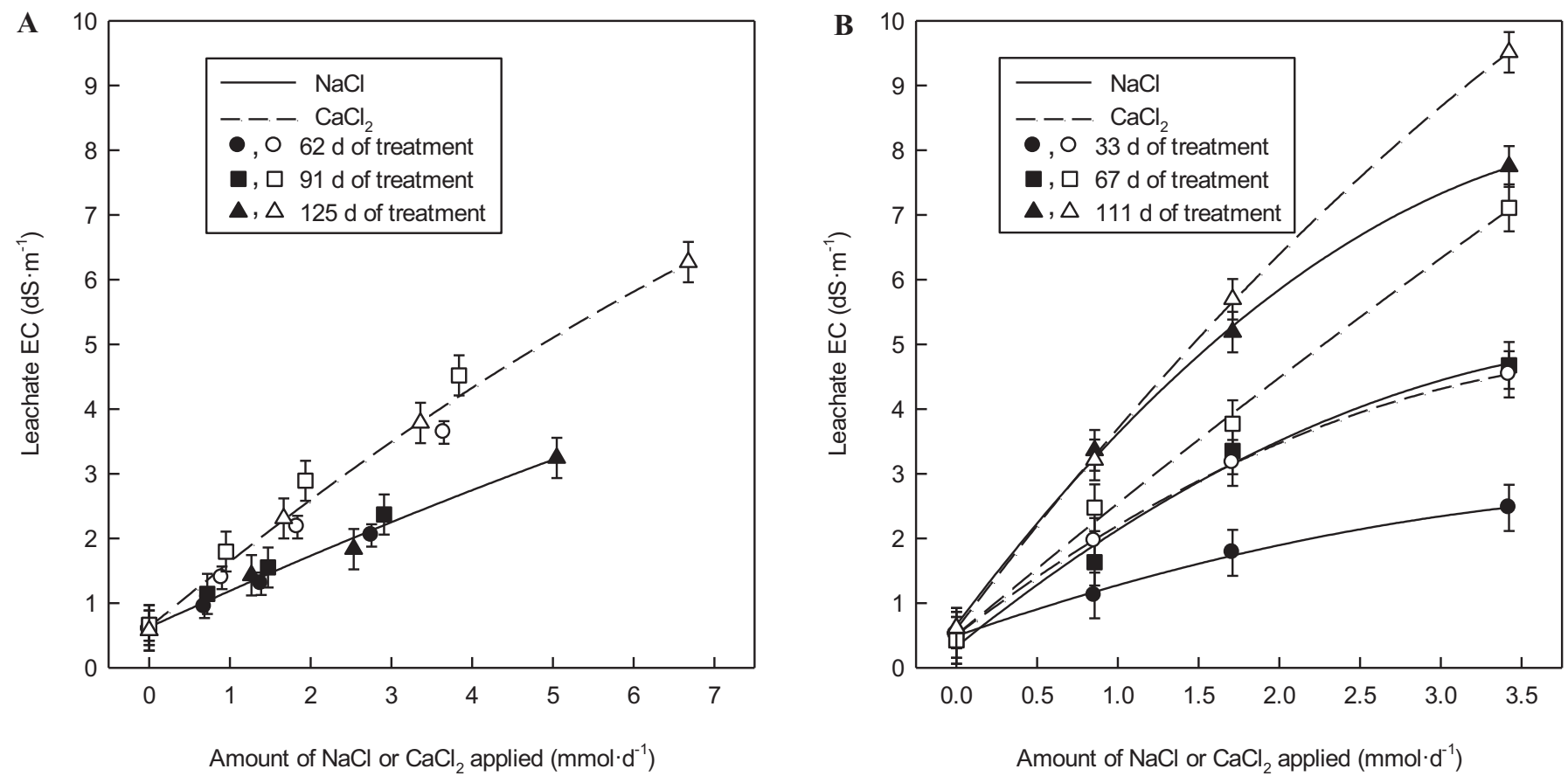

Fig. 1. Relationship between the amount of $\mathrm{NaCl}$ or $\mathrm{CaCl}_{2}$ applied and electrical conductivity (EC) of the pour-through leachate after 62,91 , and $125 \mathrm{~d}$ of treatment on (A) 'Bluecrop' blueberry in Expt. 1 and after 33, 67, and $111 \mathrm{~d}$ of treatment on (B) 'Springhigh' blueberry in Expt. 2. Data were fit using secondorder polynomials. Each symbol represents the mean of six replicates, and error bars indicate the least significant difference at the $5 \%$ level. 

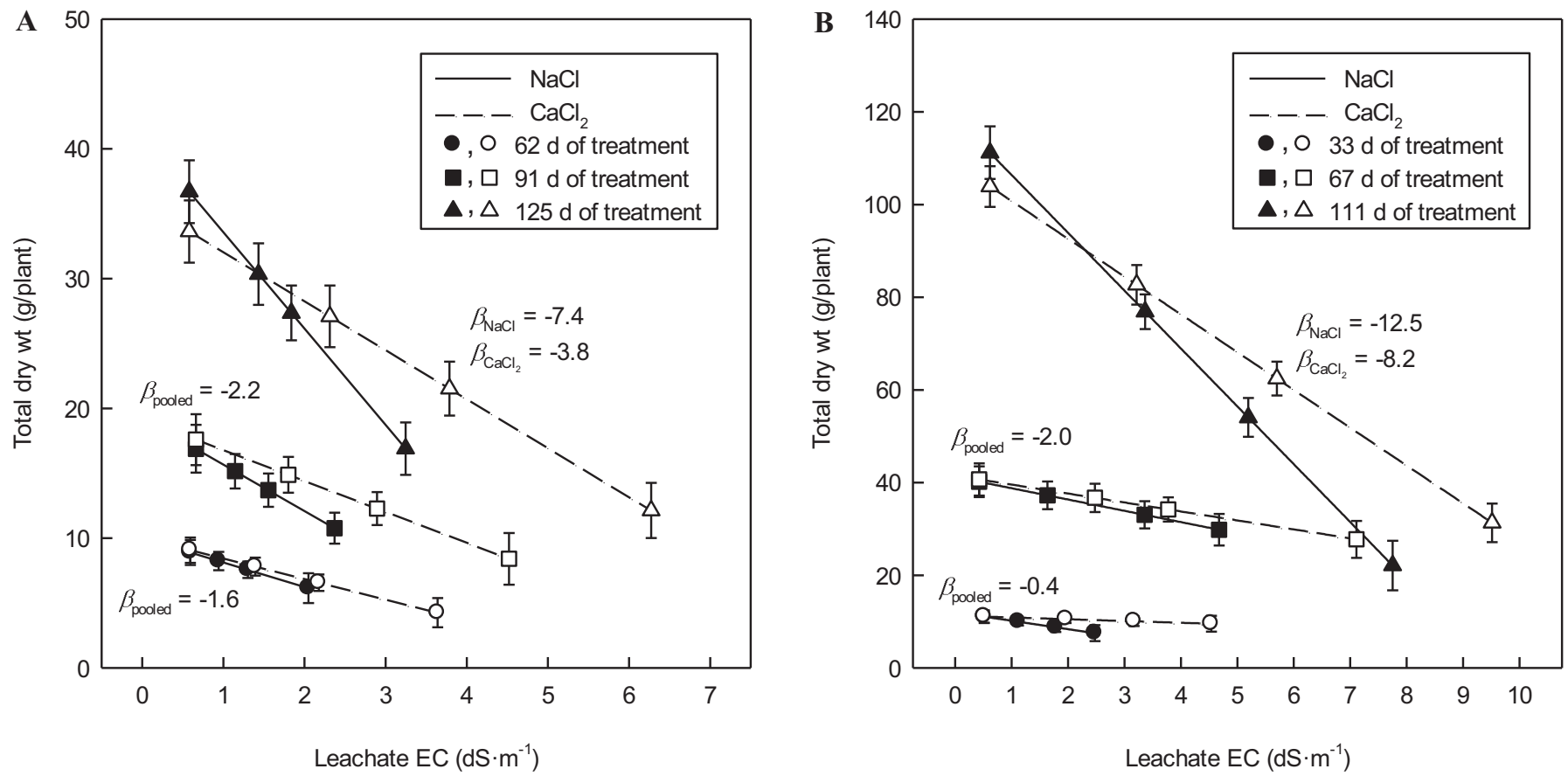

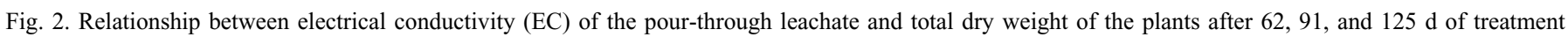
with $\mathrm{NaCl}$ or $\mathrm{CaCl}_{2}$ on (A) 'Bluecrop' blueberry in Expt. 1, and after 33, 67, and $111 \mathrm{~d}$ of treatment with $\mathrm{NaCl}$ or $\mathrm{CaCl}$, on (B) ' $\mathrm{Springhigh}$ ' blueberry in Expt. 2. Each symbol represents the mean of six replicates, and error bars indicate the least significant difference at the $5 \%$ level. Regression coefficients $(\beta)$ are presented for significant linear relationships between leachate $\mathrm{EC}$ and total dry weight $(P<0.01)$. One $\beta$ is shown when the response to $\mathrm{NaCl}$ and $\mathrm{CaCl} \mathrm{C}_{2}$ is similar on a given day, and two are shown when the response is different.

Plant growth and biomass allocation. Total dry weight of the plants was negatively correlated to EC of the pour-through leachate and, depending on the source and duration of the salinity treatment, decreased linearly at a rate of 1.6 to 7.4 $\mathrm{g} \cdot \mathrm{dS}^{-1} \cdot \mathrm{m}^{-1}$ in 'Bluecrop' (Expt. 1) and $0.4-12.5 \mathrm{~g} \cdot \mathrm{dS}^{-1} \cdot \mathrm{m}^{-1}$ in 'Springhigh' (Expt. 2) (Fig. 2A and B). In both cultivars, reduction in total dry weight was similar between the two salinity sources initially, but by $91 \mathrm{~d}$ or later, reductions were greater with $\mathrm{NaCl}$ than with $\mathrm{CaCl}_{2}$ in each part of the plant, including in the leaves, stems, and roots (Table 2). In most cases, differential effects of the two salt sources on tissue dry weight occurred at higher salinity levels and were mostly absent when EC of the leachate was $\leq 2 \mathrm{dS} \cdot \mathrm{m}^{-1}$.

Salinity reduced allocation of biomass to leaves (in favor of stems and/or roots) at each harvest date in 'Bluecrop' and at the final harvest date in 'Springhigh' (Table 2). However, with a few exceptions, allocation of biomass among each organ was generally similar between the two salt sources. Exceptions included relationships between leachate EC and allocation of biomass to leaves and roots at $91 \mathrm{~d}$ in 'Bluecrop' and to leaves, stems, and roots at $111 \mathrm{~d}$ in 'Springhigh'. In the first case, 'Bluecrop' allocated less biomass to roots in favor of leaves when plants were treated with $\mathrm{NaCl}$ and less biomass to leaves in favor of roots when plants were treated with $\mathrm{CaCl}_{2}$. In the second case, 'Springhigh' allocated less biomass to leaves and roots in favor of stems when plants were treated with $\mathrm{NaCl}$, but allocation was unaffected by $\mathrm{CaCl}_{2}$. Furthermore, when EC was normalized to $2 \mathrm{dS} \cdot \mathrm{m}^{-1}$ in 'Springhigh', plants treated with $\mathrm{NaCl}$ allocated less biomass to leaves at $33 \mathrm{~d}$ than those treated with $\mathrm{CaCl}_{2}$.

Mycorrhizal COLONIzATION. Mycorrhizal colonization was affected by salinity at 91 and $125 \mathrm{~d}$ of treatment in 'Bluecrop' and at $111 \mathrm{~d}$ of treatment in 'Springhigh' (Table 2). On these dates, the percentage of root length that was colonized by the fungi declined with increasing levels of salinity in 'Bluecrop' and, when EC was normalized to $2 \mathrm{dS} \cdot \mathrm{m}^{-1}$, was lower by an average of $10 \%$ with $\mathrm{NaCl}$ than with $\mathrm{CaCl}_{2}$ in both cultivars.

NuTRIENT UPTAKE AND CONCENTRATIONS. As expected, uptake of $\mathrm{Na}$ was greater in both cultivars when plants were treated with $\mathrm{NaCl}$ than with $\mathrm{CaCl}_{2}$, whereas uptake of $\mathrm{Ca}$ was greater when the plants were treated with $\mathrm{CaCl}_{2}$ than with $\mathrm{NaCl}$ (Table 3). Furthermore, $\mathrm{CaCl}_{2}$ salinity had no effect on uptake or concentration of $\mathrm{Na}$ in the plant tissues, but $\mathrm{NaCl}$ salinity reduced $\mathrm{Ca}$ uptake in both cultivars and resulted in lower concentrations of $\mathrm{Ca}$ in the leaves and stems of 'Bluecrop' and in each part of the plant in 'Springhigh'. By the end of the experiment for 'Bluecrop', Na concentrations averaged 75.8, 1.4, and $1.8 \mathrm{mg} \cdot \mathrm{g}^{-1}$ in the leaves, stems, and roots, respectively, of plants treated with the highest level of $\mathrm{NaCl}$ but was $<0.2 \mathrm{mg} \cdot \mathrm{g}^{-1}$ in each tissue of those treated with the highest level of $\mathrm{CaCl}_{2}$. Calcium concentrations, on the other hand, averaged 2.1, 3.6, and $1.6 \mathrm{mg} \cdot \mathrm{g}^{-1}$, respectively, in each tissue of plants treated with the highest level of $\mathrm{NaCl}$ and $11.0,12.6$, and $3.3 \mathrm{mg} \cdot \mathrm{g}^{-1}$, respectively, in those treated with the highest level of $\mathrm{CaCl}_{2}$. Similar differences were observed by the end of the experiment for 'Springhigh'. In this case, Na concentrations averaged 18.9, 4.5, and $4.8 \mathrm{mg} \cdot \mathrm{g}^{-1}$, respectively, in plants treated with the highest level of $\mathrm{NaCl}$ and $<0.6 \mathrm{mg} \cdot \mathrm{g}^{-1}$ in each tissue in those treated with the highest level of $\mathrm{CaCl}_{2}$. Calcium concentrations averaged $3.3,1.6$, and $1.7 \mathrm{mg} \cdot \mathrm{g}^{-1}$, respectively, in plants treated with the highest level of $\mathrm{NaCl}$ and $17.2,6.4$, and $3.4 \mathrm{mg} \cdot \mathrm{g}^{-1}$, respectively, in those treated with the highest level of $\mathrm{CaCl}_{2}$.

Both of the salts increased $\mathrm{Cl}$ uptake, particularly when $\mathrm{NaCl}$ was applied (Table 3 ). In many cases, $\mathrm{NaCl}$ salinity resulted in higher concentrations of $\mathrm{Cl}$ in the plant tissues than $\mathrm{CaCl}_{2}$ in 
both cultivars. This was partially because twice as much $\mathrm{Cl}^{-}$ was applied with $\mathrm{NaCl}$ than with an equivalent mmol addition of $\mathrm{CaCl}_{2}$. By the end of the experiments, the concentration of $\mathrm{Cl}$ in 'Bluecrop' averaged 2.2, 2.4, and $3.5 \mathrm{mg} \cdot \mathrm{g}^{-1}$ in in the leaves, stem, and roots, respectively, in plants treated with the highest level of $\mathrm{NaCl}$ and $6.8,4.1$, and $3.7 \mathrm{mg} \cdot \mathrm{g}^{-1}$, respectively, in those treated with the highest level of $\mathrm{CaCl}_{2}$. In 'Springhigh', $\mathrm{Cl}$ concentrations averaged $19.3,7.2$, and $3.0 \mathrm{mg} \cdot \mathrm{g}^{-1}$ with the highest level of $\mathrm{NaCl}$, and $19.8,6.7$, and $4.6 \mathrm{mg} \cdot \mathrm{g}^{-1}$ with the highest level of $\mathrm{CaCl}_{2}$.

Table 2. Effects of salinity from $\mathrm{NaCl}$ or $\mathrm{CaCl}_{2}$ on plant tissue dry weight, biomass allocation, and mycorrhizal colonization in 'Bluecrop' (Expt. 1) and 'Springhigh' (Expt. 2) blueberry.

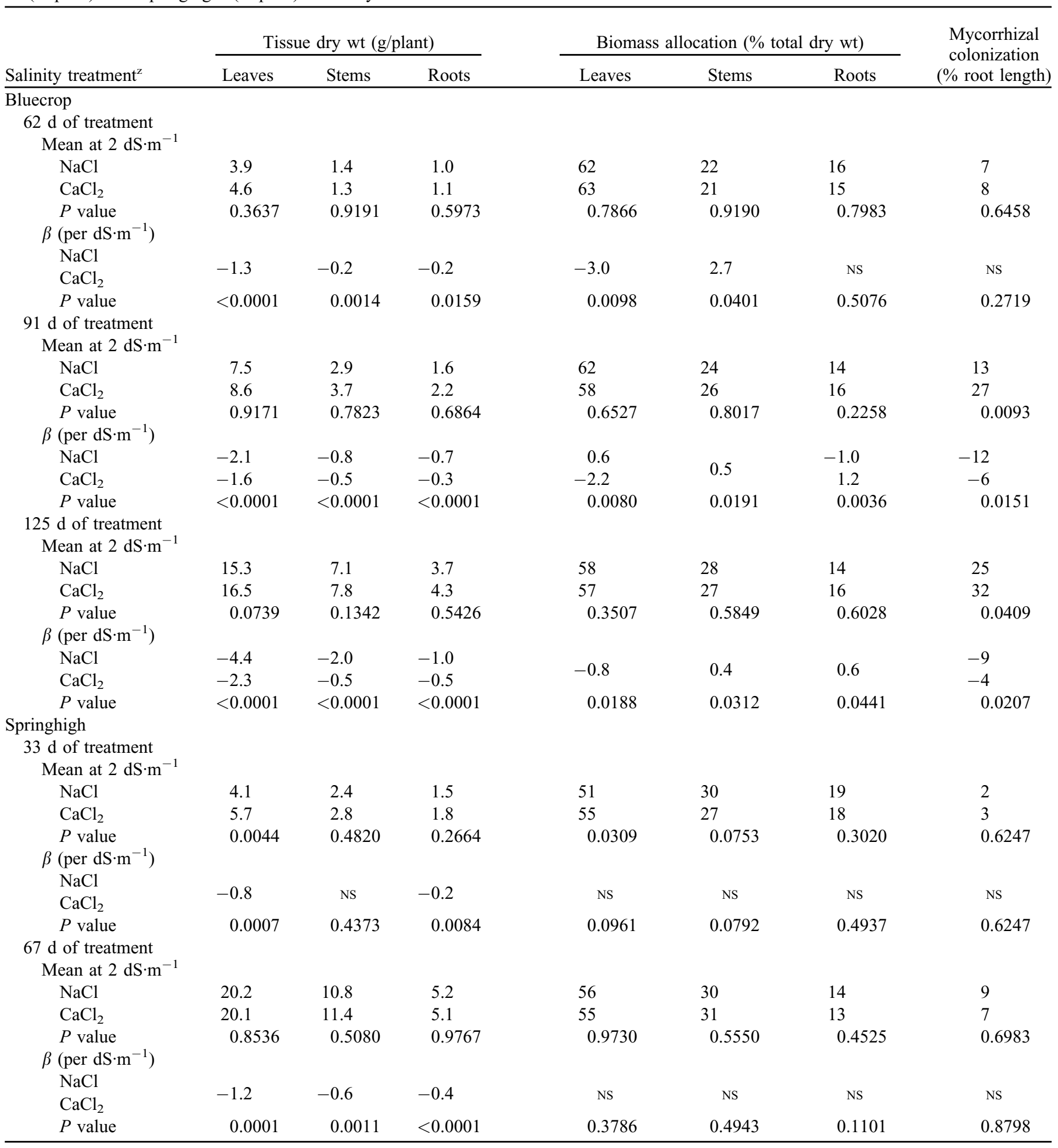


Table 2. (Continued) Effects of salinity from $\mathrm{NaCl}$ or $\mathrm{CaCl}_{2}$ on plant tissue dry weight, biomass allocation, and mycorrhizal colonization in 'Bluecrop' (Expt. 1) and 'Springhigh' (Expt. 2) blueberry.

\begin{tabular}{|c|c|c|c|c|c|c|c|}
\hline Salinity treatment ${ }^{\mathrm{z}}$ & Leaves & Stems & Roots & Leaves & Stems & Roots & $\begin{array}{c}\text { Mycorrhizal } \\
\text { colonization } \\
\text { (\% root length) }\end{array}$ \\
\hline $\mathrm{NaCl}$ & 47.1 & 33.5 & 10.6 & 50 & 38 & 11 & 12 \\
\hline $\mathrm{CaCl}_{2}$ & 43.8 & 31.0 & 12.6 & 51 & 37 & 13 & 20 \\
\hline $\mathrm{NaCl}$ & -6.8 & -3.7 & -2.0 & -1.4 & 2.0 & -0.6 & \\
\hline $\mathrm{CaCl}_{2}$ & -4.2 & -3.1 & -1.4 & NS & NS & NS & NS \\
\hline$P$ value & $<0.0001$ & $<0.0001$ & $<0.0001$ & 0.0101 & 0.0004 & 0.0141 & 0.6841 \\
\hline
\end{tabular}

${ }^{\mathrm{z}}$ Means $(\mathrm{n}=24)$ of $\mathrm{NaCl}$ and $\mathrm{CaCl}_{2}$ were estimated at a leachate electrical conductivity $(\mathrm{EC})$ of $2 \mathrm{dS} \cdot \mathrm{m}^{-1}$. Regression coefficients $(\beta)$ are presented for significant linear relationships between leachate EC and tissue dry weight, biomass allocation, and mycorrhizal colonization. One $\beta$ is shown when the response to $\mathrm{NaCl}$ and $\mathrm{CaCl}_{2}$ is similar on a given day, and two are shown when the response is different.

${ }^{\mathrm{NS}}$ Nonsignificant.

Other nutrients were also affected by salinity (Table 4). In one or both cultivars, the concentration of $\mathrm{N}, \mathrm{P}, \mathrm{Cu}$, and $\mathrm{Zn}$ in the plants increased with salinity on at least one harvest date, whereas the concentration of $\mathrm{K}, \mathrm{Mg}, \mathrm{S}, \mathrm{Fe}$, and $\mathrm{Mn}$ often declined with salinity. Boron was the only nutrient that responded differently to salinity in the two cultivars. In this case, the concentration of B increased with salinity in 'Bluecrop' and, with one exception (i.e., $\mathrm{CaCl}_{2}$ salinity at $111 \mathrm{~d}$ ), declined with salinity in 'Springhigh'. In most cases, the response of these nutrients to salinity was similar between the two salts; however,

Table 3. Effects of salinity from $\mathrm{NaCl}$ or $\mathrm{CaCl}_{2}$ on total uptake and plant tissue concentrations of $\mathrm{Na}, \mathrm{Ca}, \mathrm{K}$, and $\mathrm{Cl}$ in ' $\mathrm{Bluecrop}$ ' (Expt. 1) and 'Springhigh' (Expt. 2) blueberry.

\begin{tabular}{|c|c|c|c|c|c|c|c|c|c|c|c|c|}
\hline \multirow[b]{2}{*}{ Salinity treatment ${ }^{z}$} & \multirow{2}{*}{$\begin{array}{l}\text { Na uptake } \\
\text { (mg/plant) }\end{array}$} & \multicolumn{3}{|c|}{$\mathrm{Na}$ concn $\left(\mathrm{mg} \cdot \mathrm{g}^{-1}\right)$} & \multirow{2}{*}{$\begin{array}{l}\text { Ca uptake } \\
\text { (mg/plant) }\end{array}$} & \multicolumn{3}{|c|}{$\mathrm{Ca}$ concn $\left(\mathrm{mg} \cdot \mathrm{g}^{-1}\right)$} & \multirow{2}{*}{$\begin{array}{l}\text { Cl uptake } \\
\text { (mg/plant) }\end{array}$} & \multicolumn{3}{|c|}{$\mathrm{Cl}$ conch $\left(\mathrm{mg} \cdot \mathrm{g}^{-1}\right)$} \\
\hline & & Leaves & Stems & Roots & & Leaves & Stems & Roots & & Leaves & Stems & Roots \\
\hline \multicolumn{13}{|l|}{ Bluecrop } \\
\hline \multicolumn{13}{|c|}{ Mean at $2 \mathrm{dS} \cdot \mathrm{m}^{-1}$} \\
\hline $\mathrm{NaCl}$ & 15 & 2.65 & 1.58 & 1.95 & 15 & 2.3 & 3.2 & 1.8 & 9 & 0.84 & 1.53 & 3.28 \\
\hline $\mathrm{CaCl}_{2}$ & 1 & 0.14 & 0.35 & 0.21 & 27 & 3.7 & 6.3 & 2.5 & 8 & 1.17 & 1.52 & 2.73 \\
\hline $\mathrm{NaCl}$ & 8 & 1.68 & 0.71 & 0.90 & -8 & -0.28 & -0.82 & NS & \multirow[b]{2}{*}{2.9} & 0.32 & \multirow[b]{2}{*}{0.76} & 1.53 \\
\hline $\mathrm{CaCl}_{2}$ & NS & NS & NS & NS & NS & 0.57 & 0.87 & 0.27 & & 0.79 & & 0.70 \\
\hline$P$ value & $<0.0001$ & $<0.0001$ & $<0.0001$ & $<0.0001$ & 0.0015 & $<0.0001$ & 0.0005 & 0.0007 & $<0.0001$ & 0.0003 & $<0.0001$ & 0.0239 \\
\hline \multicolumn{13}{|c|}{$91 \mathrm{~d}$ of treatment } \\
\hline \multicolumn{13}{|c|}{ Mean at $2 \mathrm{dS} \cdot \mathrm{m}^{-1}$} \\
\hline $\mathrm{NaCl}$ & 19 & 2.32 & 0.84 & 1.03 & -13 & -0.28 & -0.44 & NS & 16.1 & 1.54 & 1.34 & 1.41 \\
\hline $\mathrm{CaCl}_{2}$ & NS & NS & NS & NS & NS & 0.98 & 1.21 & 0.15 & 5.3 & 0.87 & 0.69 & 0.74 \\
\hline$P$ value & $<0.0001$ & $<0.0001$ & $<0.0001$ & $<0.0001$ & $<0.0001$ & $<0.0001$ & 0.0003 & 0.0127 & $<0.0001$ & 0.0021 & $<0.0001$ & 0.0014 \\
\hline \multicolumn{13}{|c|}{$125 \mathrm{~d}$ of treatment } \\
\hline \multicolumn{13}{|c|}{ Mean at $2 \mathrm{dS} \cdot \mathrm{m}^{-1}$} \\
\hline $\mathrm{NaCl}$ & 28 & 1.99 & 0.87 & 1.02 & 69 & 2.3 & 3.7 & 1.6 & 26 & 1.23 & 1.35 & 2.02 \\
\hline $\mathrm{CaCl}_{2}$ & 3 & 0.10 & 0.12 & 0.11 & 106 & 3.8 & 6.1 & 2.0 & 24 & 0.70 & 1.23 & 1.91 \\
\hline$P$ value & 0.0059 & $<0.0001$ & 0.0863 & 0.0561 & 0.0051 & 0.0406 & 0.0437 & 0.4874 & 0.6316 & 0.0231 & 0.0158 & 0.1119 \\
\hline \multicolumn{13}{|c|}{$\beta\left(\right.$ per $\left.\mathrm{dS} \cdot \mathrm{m}^{-1}\right)$} \\
\hline $\mathrm{NaCl}$ & 14 & 1.81 & 0.39 & 0.50 & -22 & -0.15 & -0.14 & NS & 12.1 & & 1.07 & 0.98 \\
\hline $\mathrm{CaCl}_{2}$ & NS & NS & NS & NS & NS & 1.35 & 1.31 & 0.21 & 9.2 & 1.28 & 0.62 & 0.64 \\
\hline
\end{tabular}


Table 3. (Continued) Effects of salinity from $\mathrm{NaCl}$ or $\mathrm{CaCl}_{2}$ on total uptake and plant tissue concentrations of $\mathrm{Na}$, $\mathrm{Ca}$, $\mathrm{K}$, and $\mathrm{Cl}$ in 'Bluecrop' (Expt. 1) and 'Springhigh' (Expt. 2) blueberry.

\begin{tabular}{|c|c|c|c|c|c|c|c|c|c|c|c|c|}
\hline \multirow[b]{2}{*}{ Salinity treatment ${ }^{\mathrm{z}}$} & \multirow{2}{*}{$\begin{array}{l}\text { Na uptake } \\
\text { (mg/plant) }\end{array}$} & \multicolumn{3}{|c|}{$\mathrm{Na}$ concn $\left(\mathrm{mg} \cdot \mathrm{g}^{-1}\right)$} & \multirow{2}{*}{$\begin{array}{l}\text { Ca uptake } \\
\text { (mg/plant) }\end{array}$} & \multicolumn{3}{|c|}{ Ca concn $\left(\mathrm{mg} \cdot \mathrm{g}^{-1}\right)$} & \multirow{2}{*}{$\begin{array}{l}\mathrm{Cl} \text { uptake } \\
\text { (mg/plant) }\end{array}$} & \multicolumn{3}{|c|}{$\mathrm{Cl}$ concn $\left(\mathrm{mg} \cdot \mathrm{g}^{-1}\right)$} \\
\hline & & Leaves & Stems & Roots & & Leaves & Stems & Roots & & Leaves & Stems & Roots \\
\hline \multicolumn{13}{|l|}{ Springhigh } \\
\hline \multicolumn{13}{|c|}{ Mean at $2 \mathrm{dS} \cdot \mathrm{m}^{-1}$} \\
\hline $\mathrm{NaCl}$ & 20 & 1.42 & 2.44 & 5.62 & 23 & 3.3 & 2.7 & 2.2 & 31 & 3.29 & 3.51 & 5.01 \\
\hline $\mathrm{CaCl}_{2}$ & 1 & 0.03 & 0.18 & 0.34 & 44 & 4.9 & 3.7 & 2.7 & 30 & 2.81 & 2.91 & 4.13 \\
\hline $\mathrm{NaCl}$ & 14 & 1.11 & 1.55 & 1.01 & -9 & -0.29 & -0.20 & -0.27 & \multirow{2}{*}{17} & \multirow{2}{*}{1.89} & 2.38 & \multirow{2}{*}{1.78} \\
\hline $\mathrm{CaCl}_{2}$ & NS & NS & NS & NS & NS & 0.93 & 0.34 & 0.17 & & & 1.74 & \\
\hline$P$ value & $<0.0001$ & $<0.0001$ & $<0.0001$ & $<0.0001$ & 0.0013 & $<0.0001$ & 0.0197 & 0.0017 & $<0.0001$ & $<0.0001$ & 0.0067 & 0.0028 \\
\hline \multicolumn{13}{|c|}{$67 \mathrm{~d}$ of treatment } \\
\hline \multicolumn{13}{|c|}{ Mean at $2 \mathrm{dS} \cdot \mathrm{m}^{-1}$} \\
\hline $\mathrm{NaCl}$ & 60 & 2.99 & 0.96 & 0.86 & -12 & -0.15 & -0.07 & -0.10 & 86 & 3.89 & 1.85 & 1.78 \\
\hline $\mathrm{CaCl}_{2}$ & NS & NS & NS & NS & 13 & 1.20 & 0.41 & 0.07 & 38 & 2.09 & 0.78 & 1.05 \\
\hline$P$ value & $<0.0001$ & $<0.0001$ & $<0.0001$ & $<0.0001$ & $<0.0001$ & $<0.0001$ & $<0.0001$ & 0.0100 & $<0.0001$ & $<0.0001$ & $<0.0001$ & 0.0033 \\
\hline \multirow{2}{*}{\multicolumn{13}{|c|}{$\begin{array}{l}111 \mathrm{~d} \text { of treatment } \\
\text { Mean at } 2 \mathrm{dS} \cdot \mathrm{m}^{-1}\end{array}$}} \\
\hline & & & & & & & & & & & & \\
\hline $\mathrm{NaCl}$ & 147 & 2.34 & 1.54 & 1.72 & 289 & 4.0 & 2.1 & 2.0 & 167 & 2.66 & 1.86 & 3.10 \\
\hline $\mathrm{CaCl}_{2}$ & 26 & 0.06 & 0.47 & 0.57 & 364 & 5.8 & 2.5 & 2.3 & 170 & 2.18 & 2.13 & 2.90 \\
\hline$P$ value & 0.00861 & 0.0072 & 0.2306 & 0.0812 & 0.0552 & 0.0465 & 0.0291 & 0.4416 & 0.5524 & 0.4650 & 0.0291 & 0.4415 \\
\hline \multicolumn{13}{|l|}{$\beta\left(\right.$ per dS $\left.\cdot \mathrm{m}^{-1}\right)$} \\
\hline $\mathrm{NaCl}$ & 54 & 2.88 & 0.70 & 0.78 & -43 & -0.13 & -0.08 & -0.08 & 85 & 3.55 & 1.33 & 1.44 \\
\hline $\mathrm{CaCl}_{2}$ & NS & NS & NS & NS & 15 & 1.67 & 0.57 & 0.18 & 65 & 2.69 & 0.86 & 1.08 \\
\hline
\end{tabular}

${ }^{\mathrm{z}}$ Means $(\mathrm{n}=24)$ of $\mathrm{NaCl}$ and $\mathrm{CaCl}_{2}$ were estimated at a leachate electrical conductivity $(\mathrm{EC})$ of $2 \mathrm{dS} \cdot \mathrm{m}^{-1}$. Regression coefficients $(\beta)$ are presented for significant linear relationships between leachate EC and uptake and concentration of each nutrient. One $\beta$ is shown when the response to $\mathrm{NaCl}$ and $\mathrm{CaCl}_{2}$ is similar on a given day, and two are shown when the response is different.

${ }^{\mathrm{NS}}$ Nonsignificant.

there were a few exceptions. For example, in 'Bluecrop', concentration of $\mathrm{K}$ and $\mathrm{S}$ at $91 \mathrm{~d}$ and of $\mathrm{K}, \mathrm{Cu}$, and $\mathrm{Mn}$ at $125 \mathrm{~d}$ were either more affected by $\mathrm{NaCl}$ than by $\mathrm{CaCl}_{2}$ or affected by $\mathrm{NaCl}$ only. This was also the case for the concentrations of $\mathrm{B}$ and Fe in 'Springhigh' at $111 \mathrm{~d}$.

SALt Damage IN THE LEaVes. Leaf damage increased with the level of salinity in both cultivars and was greater with $\mathrm{CaCl}_{2}$ than with $\mathrm{NaCl}$ (Table 5). In 'Bluecrop', leaf damage differed between the salts beginning at $99 \mathrm{~d}$ of treatment but, on average, remained $<5 \%$ with $\mathrm{NaCl}$ and reached only $10 \%$ with $\mathrm{CaCl}_{2}$ (Fig. 3A). In 'Springhigh', leaf damage differed between the salts as early as $30 \mathrm{~d}$ and increased to an average of $25 \%$ with $\mathrm{NaCl}$ and $45 \%$ with $\mathrm{CaCl}_{2}$ (Fig. 3B).

\section{Discussion}

Salinity reduced the growth of highbush blueberry in the present study, but the response differed depending on the source of the salinity. Specifically, $\mathrm{NaCl}$ resulted in less plant growth than $\mathrm{CaCl}_{2}$, which was expected given the known deleterious effects of $\mathrm{Na}^{+}$on photosynthesis (Sudhir and Murthy, 2004), cell turgor (Munns 2002; Munns and Passioura, 1984), and uptake of cations and other nutrients (Grattan and Grieve, 1999). However, $\mathrm{CaCl}_{2}$ resulted in more leaf damage to the plants than $\mathrm{NaCl}$ when the plants were exposed to medium to high levels of salinity. This latter difference did not appear to be attributable to $\mathrm{Cl}^{-}$ from the salts, given that the concentration of $\mathrm{Cl}$ in the leaves was usually the same or lower in plants treated with $\mathrm{CaCl}_{2}$ than with $\mathrm{NaCl}$ at a given isosmotic level and was well below the level considered toxic to highbush blueberry $\left[26 \mathrm{mg} \cdot \mathrm{g}^{-1}\right.$ (Muralitharan et al., 1992)]. Excessive accumulation of $\mathrm{Ca}^{2+}$, on the other hand, might have somehow increased leaf damage over time. In fact, when plants were treated with a high level of $\mathrm{CaCl}_{2}$, leaf $\mathrm{Ca}$ concentrations were above the normal range for highbush blueberry [4.1-8.0 $\mathrm{mg} \cdot \mathrm{g}^{-1}$ (Hart et al., 2006)]. Because blueberry is a calcifuge and is adapted to acidic soils with low $\mathrm{Ca}^{2+}$ concentrations, the plants tend to be efficient at $\mathrm{Ca}$ uptake and have relatively low requirements for the nutrient (Bryla and Strik, 2015). Thus, when a calcifuge plant such as blueberry is exposed to high concentrations of $\mathrm{Ca}^{2+}$ in the soil, they cannot regulate $\mathrm{Ca}^{2+}$ influx and consequently accumulate excessive amounts of the ion (Wacquant and Picard, 1992). Like blueberry, Lupinus angustifolius L. has a very low Ca requirement, and growth in this species is severely depressed by higher Ca content in its tissue (Islam et al., 1987). This behavior is 
typical of calcifuges (Korcak, 1988) and might be related to insufficient capacity for compartmentation or physiological inactivation of $\mathrm{Ca}^{2+}$ (e.g., precipitation as calcium oxalate) (Marschner, 2002). High $\mathrm{Ca}$ concentrations are also known to inhibit stomatal regulation and lead to water stress in certain species, such as Tripolium pannonicum (Jacq.) Dobrocz. $[=$ Aster tripolium L. (Perera et al., 1995)] and Gerbera jamesonii Adlam (Albin-Garduño et al., 2007), and may likewise do so in blueberry.

Salinity also reduced root colonization by ericoid mycorrhizal fungi in the present study, particularly when we treated the plants with $\mathrm{NaCl}$. Similar results have been observed in plants

Table 4. Effects of salinity from $\mathrm{NaCl}$ or $\mathrm{CaCl}_{2}$ on total plant tissue concentrations of macro- and micronutrients in 'Bluecrop' (Expt. 1) and 'Springhigh' (Expt. 2) blueberry.

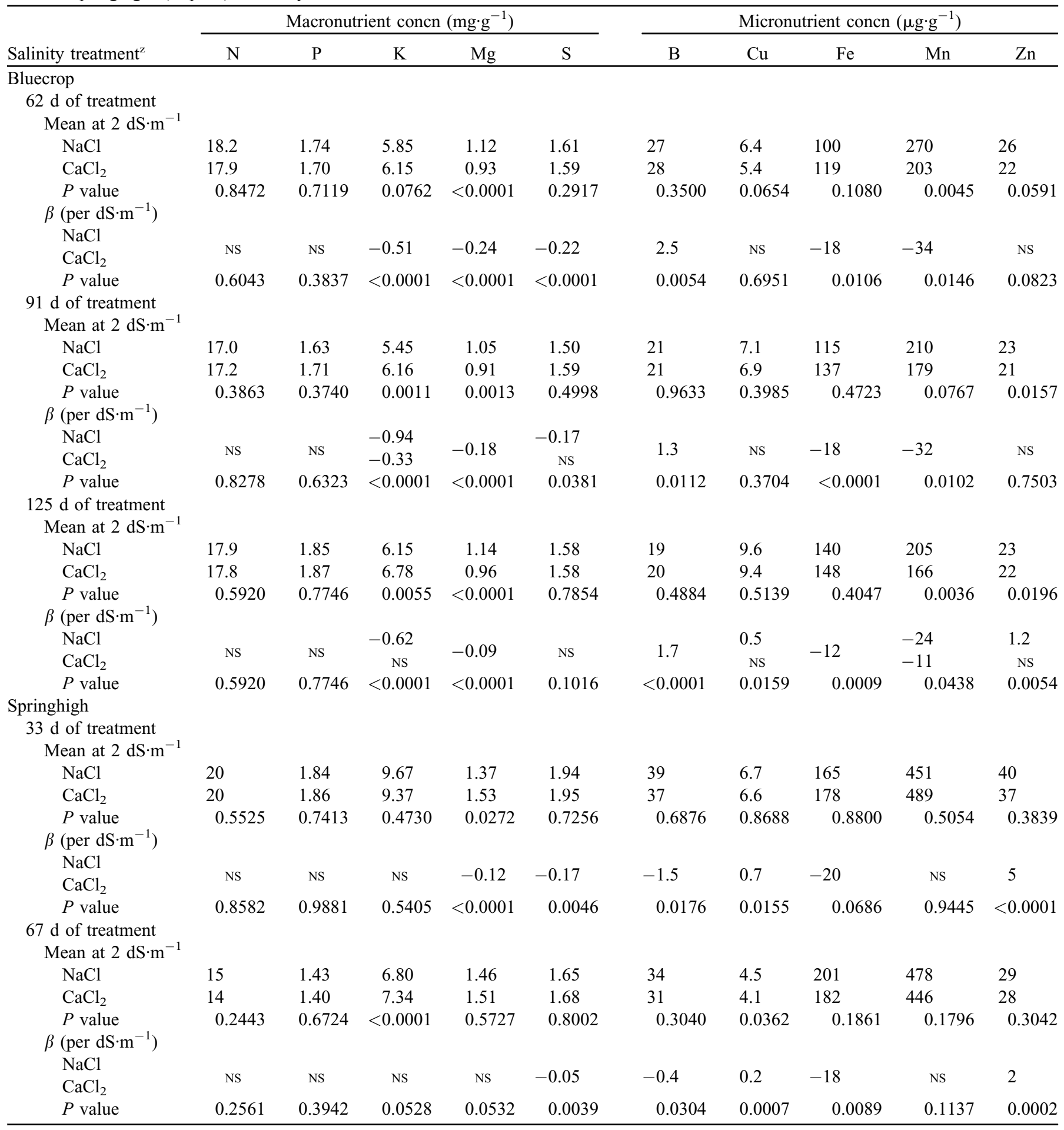


Table 4. (Continued) Effects of salinity from $\mathrm{NaCl}$ or $\mathrm{CaCl}_{2}$ on total plant tissue concentrations of macro- and micronutrients in 'Bluecrop' (Expt. 1) and 'Springhigh' (Expt. 2) blueberry.

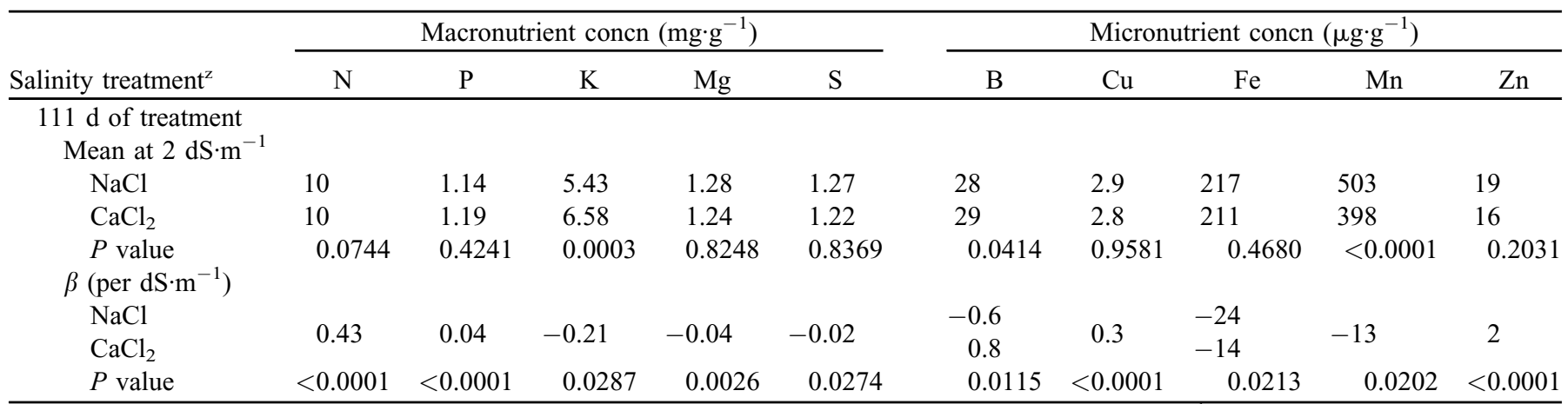

${ }^{\mathrm{z}}$ Means $(\mathrm{n}=24)$ of $\mathrm{NaCl}$ and $\mathrm{CaCl}_{2}$ were estimated at a leachate electrical conductivity (EC) of $2 \mathrm{dS} \cdot \mathrm{m}^{-1}$. Regression coefficients $(\beta)$ are presented for significant linear relationships between leachate EC and the concentration of each nutrient. One $\beta$ is shown when the response to $\mathrm{NaCl}$ and $\mathrm{CaCl}_{2}$ is similar on a given day, and two are shown when the response is different.

${ }^{\mathrm{NS}}$ Nonsignificant.

colonized by arbuscular mycorrhizal fungi (Evelin et al., 2009). Reduced colonization from salinity could be attributed to a number of factors, including osmotic effects of the salts on sporulation and hyphal development of the fungi (Estaun, 1990; Juniper and Abbott, 2006; McMillen et al., 1998), $\mathrm{Na}^{+}$and $\mathrm{Cl}^{-}$toxicity to the roots and/or fungi (Hirrel, 1981), and limited availability of carbohydrates to support the fungi brought about by the negative effects of salinity on plant growth (Thomson et al., 1990). Work is needed to determine which of these factors is affecting growth and activity of these fungi under saline conditions in blueberry.

As anticipated, high concentrations of $\mathrm{NaCl}$ reduced plant uptake of essential nutrients, including $\mathrm{K}^{+}, \mathrm{Ca}^{2+}$, and $\mathrm{Mg}^{2+}$, in both cultivars tested in the present study. In fact, leaf tissue analysis indicated that $\mathrm{Ca}$ was deficient in both cultivars $[<4.0$ $\mathrm{mg} \mathrm{g}^{-1}$ (Hart et al., 2006)] when the plants were fertigated each day with nutrient solution containing $2.8-5.0 \mathrm{mmol} \mathrm{NaCl}$. This result is similar to previous research by Wright et al. (1994), who found that increasing $\mathrm{NaCl}$ concentrations in the nutrient solution led to increases in leaf $\mathrm{Na}$ and $\mathrm{Cl}$ concentrations and decreases in leaf $\mathrm{K}$ and $\mathrm{Ca}$ concentrations in rabbiteye blueberry. Excess $\mathrm{Na}^{+}$in the root zone often causes the development of

Table 5. Leaf damage (tip burn and/or marginal necrosis) from $\mathrm{NaCl}$ or $\mathrm{CaCl}_{2}$ salinity in 'Bluecrop' (Expt. 1) and 'Springhigh' (Expt. 2) blueberry.

\begin{tabular}{|c|c|c|c|c|c|c|}
\hline \multirow{3}{*}{$\begin{array}{l}\text { Salinity } \\
\text { level }^{\mathrm{y}}\end{array}$} & \multicolumn{6}{|c|}{ Leaves with salt damage $(\% \text { of all leaves })^{z}$} \\
\hline & \multicolumn{3}{|c|}{ Bluecrop } & \multicolumn{3}{|c|}{ Springhigh } \\
\hline & $\mathrm{NaCl}$ & $\mathrm{CaCl}_{2}$ & Difference & $\mathrm{NaCl}$ & $\mathrm{CaCl}_{2}$ & Difference \\
\hline Control & $2 b^{x}$ & $2 \mathrm{~b}$ & $0^{\mathrm{NS}}$ & $6 \mathrm{~b}$ & $6 \mathrm{~d}$ & $0^{\mathrm{NS}}$ \\
\hline Low & $2 \mathrm{~b}$ & $4 \mathrm{~b}$ & $-2^{\mathrm{NS}}$ & $7 \mathrm{~b}$ & $12 \mathrm{c}$ & $-5^{\mathrm{NS}}$ \\
\hline Medium & $2 \mathrm{~b}$ & $3 \mathrm{~b}$ & $-1^{\mathrm{NS}}$ & $11 \mathrm{a}$ & $26 \mathrm{~b}$ & $-15^{* *}$ \\
\hline High & $5 \mathrm{a}$ & $16 \mathrm{a}$ & $-11 * *$ & $14 \mathrm{a}$ & $34 \mathrm{a}$ & $-20 * *$ \\
\hline
\end{tabular}

${ }^{\mathrm{z}}$ Data are pooled across seven dates measured between 52 and 120 $\mathrm{d}$ of treatment in 'Bluecrop' and 13 dates measured between 8 and $99 \mathrm{~d}$ of treatment in 'Springhigh'.

${ }^{\mathrm{y}}$ See Table 1 for the daily amount of salt applied at each level of salinity.

${ }^{x}$ Means followed by a common letter within a column are not significantly different at $P \leq 0.05$.

NS, **Nonsignificant or significant at $P \leq 0.01$, respectively. osmotic stress in fruit and vegetable crops and disrupts cell ion homeostasis by inducing both the inhibition in uptake of essential nutrients such as $\mathrm{K}^{+}, \mathrm{Ca}^{2+}$, and $\mathrm{NO}_{3}{ }^{-}$and the accumulation of $\mathrm{Na}^{+}$and $\mathrm{Cl}^{-}$(Machado and Serralheiro, 2017; Paranychianakis and Chartzoulakis, 2005). Likewise, excess $\mathrm{Ca}^{2+}$ may be problematic as well (Bernstein and Hayward, 1958; Nassery et al., 1979) and, in this study, resulted in lower concentrations of $\mathrm{K}, \mathrm{Mg}, \mathrm{S}, \mathrm{Fe}$, and $\mathrm{Mn}$ in both cultivars.

As mentioned, exposure to $\mathrm{NaCl}$ and $\mathrm{CaCl}_{2}$ increased the amount of $\mathrm{Cl}^{-}$in the shoot and root tissues of both cultivars, which like $\mathrm{Na}^{+}$can be toxic to the plants. The damaging impact of $\mathrm{Cl}^{-}$is described in the literature on blueberry (Wright et al., 1992, 1993, 1994) and other berry crops (Ehlig, 1965). Wright et al. (1994) found that excessive accumulation of $\mathrm{Cl}^{-}$in blueberry leaves parallels the onset of growth retardation, reduced photosynthesis, and leaf necrosis. This work further identified that the effects of $\mathrm{NaCl}$ on growth were more severe than the effects of the higher concentration of $\mathrm{Na}_{2} \mathrm{SO}_{4}$ at equimolar concentrations of $\mathrm{Na}^{+}$(Wright et al., 1992, 1993). In rabbiteye blueberry, leaf $\mathrm{Cl}$ concentrations were at least three times greater than root $\mathrm{Cl}$ concentrations after $63 \mathrm{~d}$ of treatment (Wright et al., 1994). We observed a similar response, but in our case, $\mathrm{Cl}$ concentrations were up to 42 times greater in the leaves than in the roots in the northern highbush cultivar, Bluecrop, and up to four times greater in the southern highbush cultivar, Springhigh. Such high $\mathrm{Cl}$ concentrations in the leaves emphasize the possibility that $\mathrm{Cl}^{-}$may be at least partly as damaging as $\mathrm{Na}^{+}$to growth and gas exchange of blueberry.

In summary, $\mathrm{NaCl}$ reduced plant growth more than $\mathrm{CaCl}_{2}$ in both northern and southern highbush blueberry, but $\mathrm{CaCl}_{2}$ resulted in greater leaf damage over time. Salinity also reduced root colonization by mycorrhizal fungi, which are beneficial to the plants for nutrient uptake. Mycorrhizal colonization was particularly affected when the plants were treated with $\mathrm{NaCl}$. Salinity from $\mathrm{NaCl}$ also reduced plant uptake of essential nutrients such as $\mathrm{K}^{+}$and $\mathrm{Ca}^{2+}$ more than salinity from $\mathrm{CaCl}_{2}$, whereas both of the salts increased the amount of $\mathrm{Cl}^{-}$in the plant tissue, which can be toxic to the plants. These results point to ion-specific effects of different salts on the plants and indicate that source is an important consideration when managing salinity in highbush blueberry. The information from this work will be 

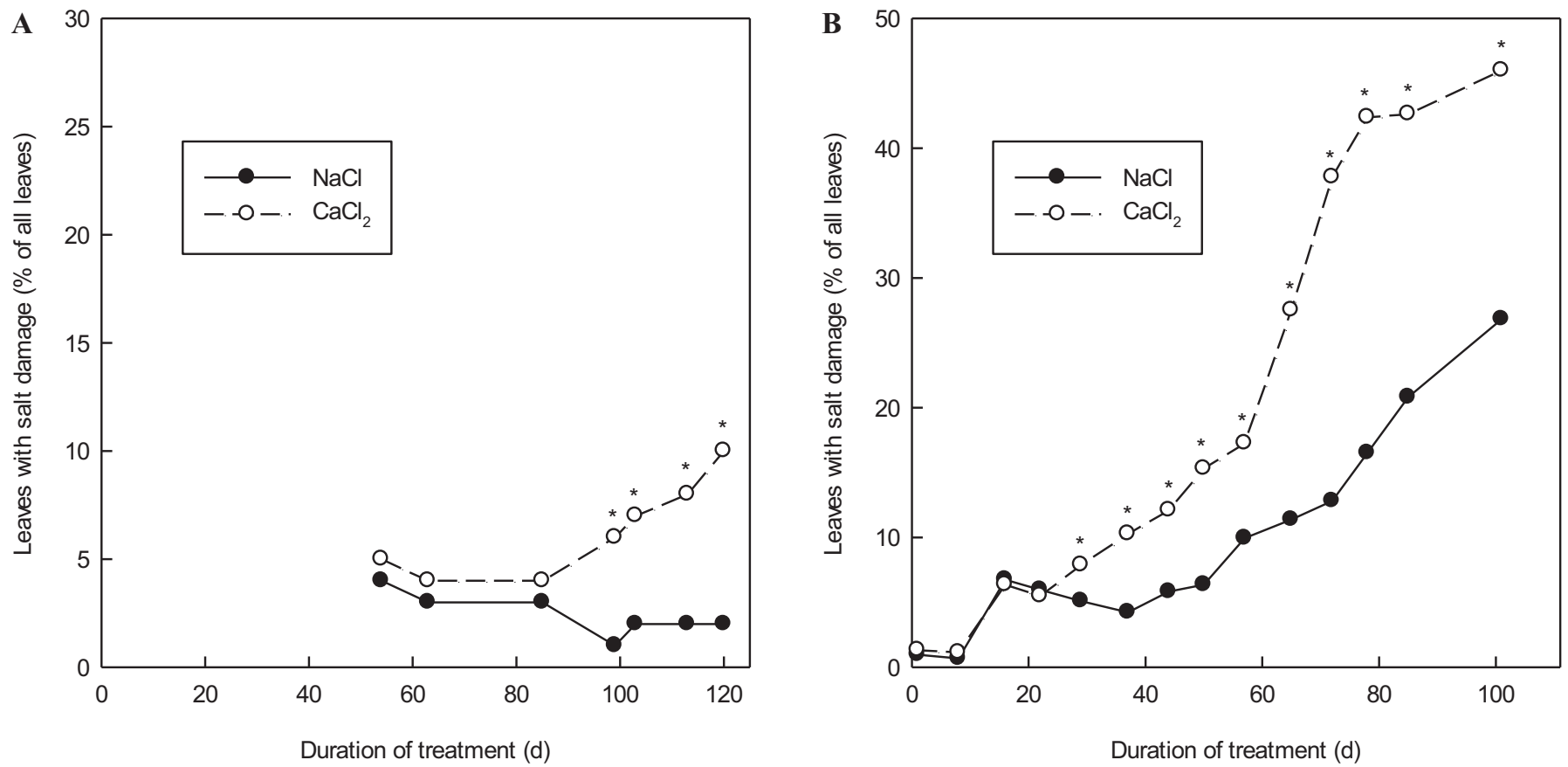

Fig. 3. Development of leaf damage (tip burn and/or marginal leaf necrosis) from $\mathrm{NaCl}$ or $\mathrm{CaCl}_{2}$ salinity in (A) 'Bluecrop' blueberry in Expt. 1, and (B) 'Springhigh' blueberry in Expt. 2. Data are pooled across three levels of salinity (see Table 1). Each symbol represents the mean of six replicates. An asterisk above the symbols on a given day indicates the means were significantly different at $P \leq 0.05$.

useful for developing better salt management practices for commercial blueberry production.

\section{Literature Cited}

Albin-Garduño, R., H.A. Zavaleta-Mancera, L.M. Ruiz-Posadas, M. Sandolval-Vill, and A. Castillo-Morales. 2007. Response of gerbera to calcium in hydroponics. J. Plant Nutr. 31:91-101, doi: 10.1080/ 01904160701741958.

Aragues, R., E. Playan, R. Ortiz, and A. Royo. 1999. A new dripinjection irrigation system for crop tolerance evaluation. Soil Sci. Soc. Amer. J. 63:1397-1404, doi: 10.2136/sssaj1999.6351397x.

Ballinger, W.E. 1962. Studies of sulfate and chloride ion effects upon Wolcott blueberry growth and composition. Proc. Am. Soc. Hort. Sci. 80:331-339.

Bernstein, L. 1964. Salt tolerance of plants. U.S. Dept. Agr., Agr. Info. Bul. 283.

Bernstein, L. and H.E. Hayward. 1958. Physiology of salt tolerance. Annu. Rev. Plant Physiol. 9:25-46, doi: 10.1146/annurev.pp.09. 060158.000325.

Bryla, D.R. and R.M.A. Machado. 2011. Comparative effects of nitrogen fertigation and granular fertilizer application on growth and availability of soil nitrogen during establishment of highbush blueberry. Front. Plant Sci. 2:46, doi: 10.3389/fpls.2011.00046.

Bryla, D.R. and C.F. Scagel. 2014. Limitations of $\mathrm{CaCl} 2$ salinity to shoot and root growth and nutrient uptake in 'Honeoye' strawberry (Fragaria $\times$ ananassa Duch.). J. Hort. Sci. Biotechnol. 89:458-470, doi: 10.1080/14620316.2014.11513107.

Bryla, D.R. and B.C. Strik. 2015. Nutrient requirements, leaf tissue standards, and new options for fertigation of northern highbush blueberry. HortTechnology 25:464 470, doi: 10.21273/HORTTECH.25.4.464.

Chapin, F.S., III and K. Van Cleve. 1989. Approaches to studying nutrient uptake, use, and loss in plants, p. 185-207. In: R.W. Pearcy, J. Ehleringer, H.A. Mooney, and P.W. Rundel (eds.). Plant physiological ecology, field methods and instrumentation. Chapman and Hall, New York, NY, doi: 10.1007/978-94-009-2221-1_10.
Cramer, G.R., A. Läuchli, and E. Epstein. 1986. Effects of $\mathrm{NaCl}$ and $\mathrm{CaCl}_{2}$ on ion activities in complex nutrient solutions and root growth of cotton. Plant Physiol. 81:792-797, doi: 10.1104/pp.81.3.792.

Ehlig, C.F. 1965. Salt tolerance of raspberry, boysenberry, and blackberry. Proc. Amer. Soc. Hort. Sci. 85:318-324.

Estaun, M.V. 1990. Effect of sodium chloride and mannitol on germination and hyphal growth of the vesicular-arbuscular mycorrhizal fungus Glomus mosseae. Agr. Ecosyst. Environ. 29:123-129, doi: 10.1016/0167-8809(90)90266-G.

Evelin, H., R. Kapoor, and B. Giri. 2009. Arbuscular mycorrhizal fungi in alleviation of salt stress: A review. Ann. Bot. 104:1263-1280, doi: 10.1093/aob/mcp251.

Fisher, P.R., A.C. Douglas, and W.R. Argo. 2006. How to soil test small containers. Greenhouse Mgt. Production 26:46-49. <https:// www.specmeters.com/assets/1/7/GMPRO_SoilTest.pdf $>$.

Gavlak, R.G., D.A. Horneck, and R.O. Miller. 2005. The soil, plant and water reference methods for the western region. 3rd ed. Western Reg. Ext. Publ. 125. Univ. Alaska, Fairbanks. 8 June 2021. <https:// www.naptprogram.org/files/napt/western-states-method-manual-2005. pdf $>$.

Giovannetti, M. and B. Mosse. 1980. An evaluation of techniques for measuring vesicular arbuscular mycorrhizal infection in roots. New Phytol. 84:489-500, doi: 10.1111/j.1469-8137.1980.tb04556.x.

Grattan, S.R. and C.M. Grieve. 1999. Salinity-mineral nutrient relations in horticultural crops. Scientia Hort. 78:127-157, doi: 10.1016/ S0304-4238(98)00192-7.

Hart, J., B. Strik, L. White, and W. Yang. 2006. Nutrient management for blueberries in Oregon. Oregon State Univ. Ext. Serv. Publ. EM 8918. 4 May 2021. <https://catalog.extension.oregonstate.edu/sites/ catalog/files/project/pdf/em8918.pdf $>$.

Hirrel, M.C. 1981. The effect of sodium and chloride salts on the germination of Gigaspora margarita. Mycologia 73:610-617, doi: 10.1080/00275514.1981.12021388.

Horneck, D.A., J.W. Ellsworth, B.G. Hopkins, D.M. Sullivan, and R.G. Stevens. 2007. Managing salt-affected soils for crop production. Pacific Northwest Ext. Publ. PNW 601-E. 4 May 2021. 
$<$ https://catalog.extension.oregonstate.edu/sites/catalog/files/project/ pdf/em8918.pdf $>$.

Islam, A.K.M.S., C.J. Asher, and D.G. Edwards. 1987. Response of plants to calcium concentration in flowing solution culture with chloride or sulphate as the counter ion. Plant Soil 98:377-395, doi: 10.1007/BF02378359.

Juniper, S. and L.K. Abbott. 2006. Soil salinity delays germination and limits growth of hyphae from propagules of arbuscular mycorrhizal fungi. Mycorrhiza 16:371-379, doi: 10.1007/s00572-0060046-9.

Korcak, R.F. 1988. Nutrition of blueberry and other calcifuges. Hort. Rev. 10:183-227, doi: 10.1002/9781118060834.ch6.

Maas, E.V. and S.R. Grattan. 1999. Crop yields as affected by salinity, p. 55-108. In: R.W. Skaggs and J. van Schilfgaarde (eds.). Agricultural drainage. Agron. Monogr. 38. Amer. Soc. Agron., Crop Sci. Soc. Amer., Soil Sci. Soc. Amer., Madison, WI, doi: 10.2134/agronmonogr38.c3.

Machado, R.M.A., D.R. Bryla, and O. Vargas. 2014. Effects of salinity induced by ammonium sulfate fertilizer on root and shoot growth of highbush blueberry. Acta Hort. 1017:407-414, doi: 10.17660/ ActaHortic.2014.1017.49.

Machado, R.M.A. and R.P. Serralheiro. 2017. Soil salinity: Effect on vegetable crop growth. Management practices to prevent and mitigate soil salinization. Horticulturae 3:30, doi: 10.3390/horticulturae 3020030.

Mallows, C.L. 1973. Some comments on Cp. Technometrics 15: 661-675, doi: 10.2307/1267380.

Marschner, H. 2002. Mineral nutrition of higher plants. 2nd ed. Academic Press, New York, NY, doi: 10.1016/C2009-0-02402-7.

McMillen, B.G., S. Juniper, and L.K. Abbott. 1998. Inhibition of hyphal growth of a vesicular-arbuscular mycorrhizal fungus in soil containing sodium chloride limits the spread of infection from spores. Soil Biol. Biochem. 30:1639-1646, doi: 10.1016/S00380717(97)00204-6.

Messiga, A.J., D. Haak, and M. Dorais. 2018. Blueberry yield and soil properties response to long-term fertigation and broadcast nitrogen. Scientia Hort. 230:92-101, doi: 10.1016/j.scienta.2017.11.019.

Munns, R. 1993. Physiological processes limiting plant growth in saline soils: Some dogmas and hypotheses. Plant Cell Environ. 16:15-24, doi: 10.1111/j.1365-3040.1993.tb00840.x.

Munns, R. 2002. Comparative physiology of salt and water stress. Plant Cell Environ. 25:239-250, doi: 10.1046/j.0016-8025.2001. 00808.x.

Munns, R. and J.B. Passioura. 1984. Effect of prolonged exposure to $\mathrm{NaCl}$ on the osmotic pressure of leaf xylem sap from intact, transpiring barley plants. Funct. Plant Biol. 11:497-507, doi: 10.1071/ PP9840497.

Munns, R. and M. Tester. 2008. Mechanisms of salinity tolerance. Annu. Rev. Plant Biol. 59:651-681, doi: 10.1146/annurev.arplant.59. 032607.092911.

Muralitharan, M.S., S. Chandler, and R.F.M. Van Stevenick. 1992. Effects of $\mathrm{NaCl}$ and $\mathrm{Na}_{2} \mathrm{SO}_{4}$ on growth and solute composition of highbush blueberry (Vaccinium corymbosum). Aust. J. Plant Physiol. 19:155-164, doi: 10.1071/PP9920155.

Nassery, H., G. Ogata, and E.V. Maas. 1979. Sensitivity of sesame to various salts. Agron. J. 71:595-597, doi: 10.2134/agronj1979.00021 962007100040018x.

Paranychianakis, N.V. and K.S. Chartzoulakis. 2005. Irrigation of Mediterranean crops with saline water: From physiology to management practices. Agr. Ecosyst. Environ. 106:171-187, doi: 10.1016/ j.agee.2004.10.006.

Paternoster, R., R. Brame, P. Mazerolle, and A. Piquero. 1998. Using the correct statistical test for the equality of regression coefficients. Criminology 36:859-866, doi: 10.1111/j.1745-9125.1998.tb01268.x.

Patten, K., E. Neuendorff, G. Nimr, V. Haby, and G. Wright. 1989. Cultural practices to reduce salinity/sodium damage of rabbiteye blueberry plants (Vaccinium ashei Reade). Acta Hort. 241:207-212, doi: 10.17660/ActaHortic.1989.241.33.

Perera, L.K.R.R., M.F. Robinson, and T.A. Mansfield. 1995. Responses of the stomata of Aster tripolium to calcium and sodium ions in relation to salinity tolerance. J. Expt. Bot. 46:623-629, doi: 10.1093/jxb/46.6.623.

Retamales, J.B. and J.F. Hancock. 2018. Blueberries. 2nd ed. CABI International, Cambridge, MA.

Richards, L.A. 1954. Origin and nature of saline and alkali soils, p. 1-6. In: L.A. Richards (ed.). Diagnosis and improvement of saline and alkali soils. Agricultural Handbook No. 60. U.S. Dept. Agr., Washington, DC, doi: 10.1126/science.120.3124.800.

Rieger, M. and P. Litvin. 1998. Ion selective electrodes for measurement of sodium and chloride in salinity experiments. J. Plant Nutr. 21:205-215, doi: 10.1080/01904169809365396.

Samson, M.-E., J. Fortin, S. Pepin, and J. Caron. 2017. Impact of potassium sulfate salinity on growth and development of cranberry plants subjected to overhead and subirrigation. Can. J. Soil Sci. 97:20-30, doi: 10.1139/cjss-2015-0111.

Scagel, C.F., A. Wagner, and P. Winiarski. 2005. Frequency and intensity of root colonization by ericoid mycorrhizal fungi in nursery production of blueberry. Small Fruits Rev. 4:95-112, doi: 10.1300/ J301v04n04_10.

Shannon, M.C., C.M. Grieve, and L.E. Francois. 1994. Whole plant response to salinity, p. 199-244. In: R.E. Wilkinson (ed.). Plant-environment interactions. Marcel Dekker, New York, NY.

Smith, S.E. and D.J. Read. 2008. Mycorrhizal symbiosis. 3rd ed. Academic Press, New York, NY, doi: 10.1016/B978-0-12-3705266.X5001-6.

Sudhir, P. and S.D.S. Murthy. 2004. Effects of salt stress on basic processes of photosynthesis. Photosynthetica 42:481-486, doi: 10.1007/ S11099-005-0001-6.

Thomson, B.D., A.D. Robson, and L.K. Abbott. 1990. Mycorrhizas formed by Gigaspora calospora and Glomus fasciculatum on subterranean clover in relation to soluble carbohydrates in roots. New Phytol. 114:217-225, doi: 10.1111/j.1469-8137.1990.tb00393.x.

Torres, A.P., M.V. Mickelbart, and R.G. Lopez. 2010. Leachate volume effects on $\mathrm{pH}$ and electrical conductivity measurements in containers obtained using a pour-through method. HortTechnology 20:608-611, doi: 10.21273/HORTTECH.20.3.608.

Vargas, O.L. and D.R. Bryla. 2015. Growth and fruit production of highbush blueberry fertilized with ammonium sulfate and urea applied by fertigation or as a granular fertilizer. HortScience 50:479-485, doi: 10.21273/HORTSCI.50.3.479.

Wacquant, J.P. and J.B. Picard. 1992. Nutritional differentiation among populations of the Mediterranean shrub Dittrichia viscosa (Asteraceae) in siliceous and calcareous habitats. Oecologia 92: 14-22, doi: 10.1007/BF00317257.

Wright, G.C., K.D. Patten, and M.C. Drew. 1992. Salinity and supplemental calcium influence growth of rabbiteye and southern highbush blueberry. J. Amer. Soc. Hort. Sci. 117:749-756, doi: 10.21273/ JASHS.117.5.749.

Wright, G.C., K.D. Patten, and M.C. Drew. 1993. Gas exchange and chlorophyll content of 'Tifblue' rabbiteye and 'Sharpblue' southern highbush blueberry exposed to salinity and supplemental calcium. J. Amer. Soc. Hort. Sci. 118:456-463, doi: 10.21273/JASHS.118. 4.456 .

Wright, G.C., K.D. Patten, and M.C. Drew. 1994. Mineral composition of young rabbiteye and southern highbush blueberry exposed to salinity and supplemental calcium. J. Amer. Soc. Hort. Sci. 119:229-236, doi: 10.21273/JASHS.119.2.229.

Wright, G.C., K.D. Patten, and M.C. Drew. 1995. Labeled sodium $\left({ }^{22} \mathrm{Na}^{+}\right)$uptake and translocation in rabbiteye blueberry exposed to sodium chloride and supplemental calcium. J. Amer. Soc. Hort. Sci. 120:117-182, doi: 10.21273/JASHS.120.2.177. 